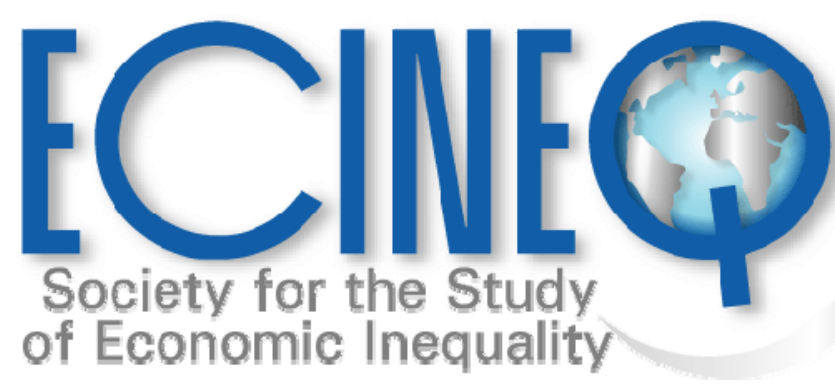

Working Paper Series

The poverty reduction capacity of private and public transfers in transition

Paolo Verme 


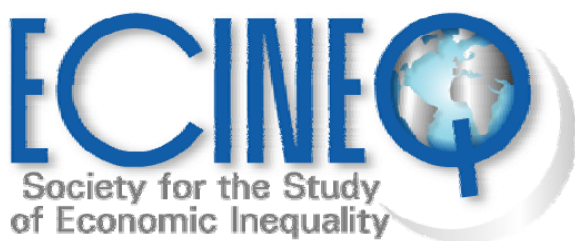

ECINEQ 2010-176

July 2010

www.ecineq.org

\title{
The poverty reduction capacity of private and public transfers in transition
}

\author{
Paolo Verme* \\ University of Torino
}

\begin{abstract}
The transitional economies of the Former Soviet Union (FSU) have enjoyed an extraordinary period of growth and poverty reduction between 2000 and 2007 and this occurred in concomitance with significant increases in private and public transfers to households. The paper assesses the relative importance of these transfers for welfare and poverty in Moldova, the poorest country in Europe. A longitudinal analysis based on panel data reveals that private transfers and social insurance transfers are effective in improving welfare and reducing poverty whereas social assistance transfers have little or no effect. Social insurance and social assistance seem to have swapped roles. Social insurance is most relevant for lifting people out of poverty while social assistance - if anything - has a small role in protecting the non-poor from falling into poverty. We also find that the different types of transfers do not crowd-out each other and that social insurance may in fact reinforce the capacity of private transfers to reduce poverty. Such findings have several policy implications for the near future: a) Poor households in FSU transitional economies remain highly vulnerable to shocks in public and private transfers; b) the 2008-2009 recession is likely to expose this vulnerability and result in a surge in poverty larger than expected and c) the social assistance systems remain in great need of pro-poor reforms and cannot currently provide an adequate protection from economic shocks.
\end{abstract}

Keywords: Private transfers, social insurance, social assistance, transitional economies. JEL Classification: H5, I3, O1, P2.

\footnotetext{
*Address of correspondence: Department of Economics "S. Cognetti de Martiis", University of Torino,
} Via Po 53, 10124 Torino, Italy. paolo.verme@unito.it 